\title{
A century of grazing: The value of long-term research
}

\section{Matt A. Sanderson, Mark A. Liebig, John R. Hendrickson, Scott L. Kronberg, David Toledo, Justin D.}

Derner, and Justin L. Reeves

$\mathrm{L}$ ong-term research is critical to understanding the sustainability of agroecosystems. This is especially true for rangelands in an era of extreme weather, climate change, and land use change. Since its inception in 1912, the USDA Agricultural Research Service, Northern Great Plains Research Laboratory (NGPRL) at Mandan, North Dakota, has focused on the ecology, management, and sustainability of native rangeland. A century ago, Johnson Thatcher Sarvis and a small group of scientists at the NGPRL set out to answer a very practical question: how many acres of native prairie does it take to support a steer during the grazing season? To answer that question they began a stocking rate study in 1915 on 101 ha $(250 \mathrm{ac})$ of native mixed-grass prairie. Part of that original experiment continues today as one of the longest running grazing experiments in North America. Scientific accomplishments from the long-term research have been summarized recently (Sanderson et al. 2015). Here we describe how the long-term research site is being leveraged for the future.

\section{CONTEXT OF THE \\ ORIGINAL EXPERIMENT}

The grazing experiment began in 1915 on a native prairie that had been hayed but was never tilled, fertilized, or planted (figure 1). The original vegetation, typical of the northern mixed-grass prairie, was dominated by graminoids including blue grama (Bouteloua gracilis [H.B.K.] Lag. ex Griffiths), needle-and-thread grass (Hesperostipa comata [Trin. and Rupr.] Barkworth), and prairie Junegrass (Koeleria

Matt A. Sanderson is research leader, Mark A. Liebig is a soil scientist, John R. Hendrickson is a rangeland management specialist, Scott L. Kronberg is an animal scientist, and David Toledo is a rangeland management specialist at the Northern Great Plains Research Laboratory in Mandan, North Dakota. Justin D. Derner is research leader and Justin L. Reeves is a research ecologist at the Rangeland Resources Research Unit in Cheyenne, Wyoming. macrantha [Ledeb.] J.A. Schultes), along with threadleaf (Carex filifolia Nutt.) and needleleaf sedge (Carex duriuscula C.A. Mey). Common forbs included cudleaf sagewort (Artemisia ludoviciana Nutt.), fringed sage (Artemisia frigida Willd.), and silverleaf scurf pea (Pediomelum argophyllum [Pursh.] J. Grimes) (Sarvis 1920).

In 1916, four pastures of 12.1, 20.2, 28.3 , and 40.5 ha $(30,50,70$, and $100 \mathrm{ac})$ were established and each stocked with 10 beef steers. Pastures were stocked continuously beginning in mid-May until early to mid-October each year. After 1945, part of the stocking rate experiment was discontinued to accommodate new forage and grazing research. The lightly stocked and heavily stocked pastures, however, have been maintained under the same management (with some modification of pasture sizes) from 1945 to the present.

\section{LONG-TERM LIVESTOCK PRODUCTIVITY AND CLIMATE RELATIONSHIPS}

Early data (1916 to 1940) provided some of the first long-term information on grazing management of northern Great
Plains mixed-grass prairie (Sarvis 1941). In addition to determining an optimum stocking rate, quantitative relationships were developed among precipitation, soil moisture, forage productivity, and livestock productivity (Rogler and Haas 1947). Because of the long-term nature of the data, we have been able to combine it with other datasets from the northern Great Plains to examine long-term (>50 years) relationships between climate and livestock productivity (Reeves et al. 2014, 2015). A common finding of these long-term analyses was that beef production increased with cool, wet springs and longer, cooler growing seasons across the region (Reeves et al. 2015). Future climate change scenarios for the northern Great Plains suggest greater spring and winter precipitation and higher spring temperatures. Applying our results to this scenario, we would expect livestock production (and perhaps livestock numbers) to increase on the northern Great Plains. Climate variability is expected to increase with climate change; thus, future research will combine long-term data with near-

\section{Figure 1}

Field technician sampling native vegetation in the long-term pastures in 1927.

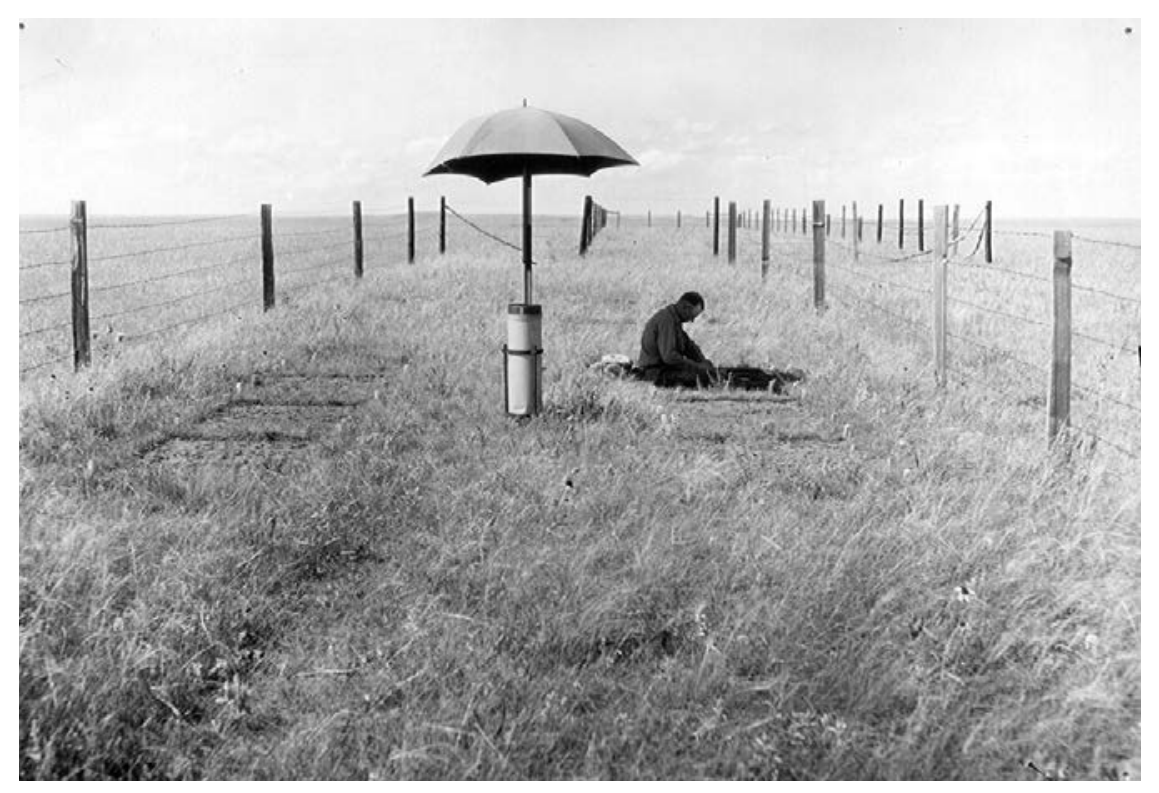


term weather forecasts to assist ranchers with risk management decisions on stocking rates and grazing management.

\section{VEGETATION CHANGE AND MECHANISMS OF INVASION}

The long-term experiment demonstrated the resilience of the native vegetation in response to the severe drought of the 1930s. Populations of many native grasses such as needle-and-thread and prairie Junegrass were severely reduced by the megadrought of the 1930s. These species rebounded with greater rainfall in the 1940s. Interestingly, however, the native prairie has not been as resilient to recent events of above normal rainfall. A major shift in vegetation occurred in the 1990s when Kentucky bluegrass (Poa pratensis L.) began to replace native grasses, such as blue grama (figure $2)$. The shift to this exotic cool-season grass coincided with a significant change in climate on the northern Great Plains involving longer growing seasons and increased precipitation. We suspect that a series of drought years in the 1980s may have compromised the competitive ability of the native cool-season grasses resulting in vegetation gaps vulnerable to Kentucky bluegrass colonization. Once established, the Kentucky bluegrass benefitted from the higher than normal precipitation in 15 of the last 24 years, which along with a longer frost-free period provided a competitive advantage and enabled it to spread rapidly (Toledo et al. 2014). Invasion of native grassland by cool-season grasses may compromise ecosystem functions such as water and nutrient cycling and wildlife habitat (Toledo et al. 2014). Understanding this change in vegetation and its relation to long-term climate trends is an ongoing research effort at the NGPRL. Studies on the potential mechanisms of invasion are also underway (figure 3). Preliminary results suggest that Kentucky bluegrass lowers species richness at the plot level but does not affect species richness at the landscape level. There also appears to be more nitrogen $(\mathrm{N})$ and carbon (C) aboveground and belowground in areas dominated by Kentucky bluegrass compared to paired control areas. The increase in aboveground $\mathrm{C}$ and $\mathrm{N}$ is driven by an increase in biomass, not by an increase in $\mathrm{C}$ or $\mathrm{N}$ concentration.

\section{Figure 2}

Relative foliar cover of blue grama and Kentucky bluegrass in (a) lightly and (b) heavily stocked pastures of mixed-grass prairie near Mandan, North Dakota. Data from 1947 are relative foliar cover from visual estimates. Data from 1964 to 2014 are relative foliar cover from point frame measurements. The 1947 to 1994 data are from Frank et al. (1995).

(a)

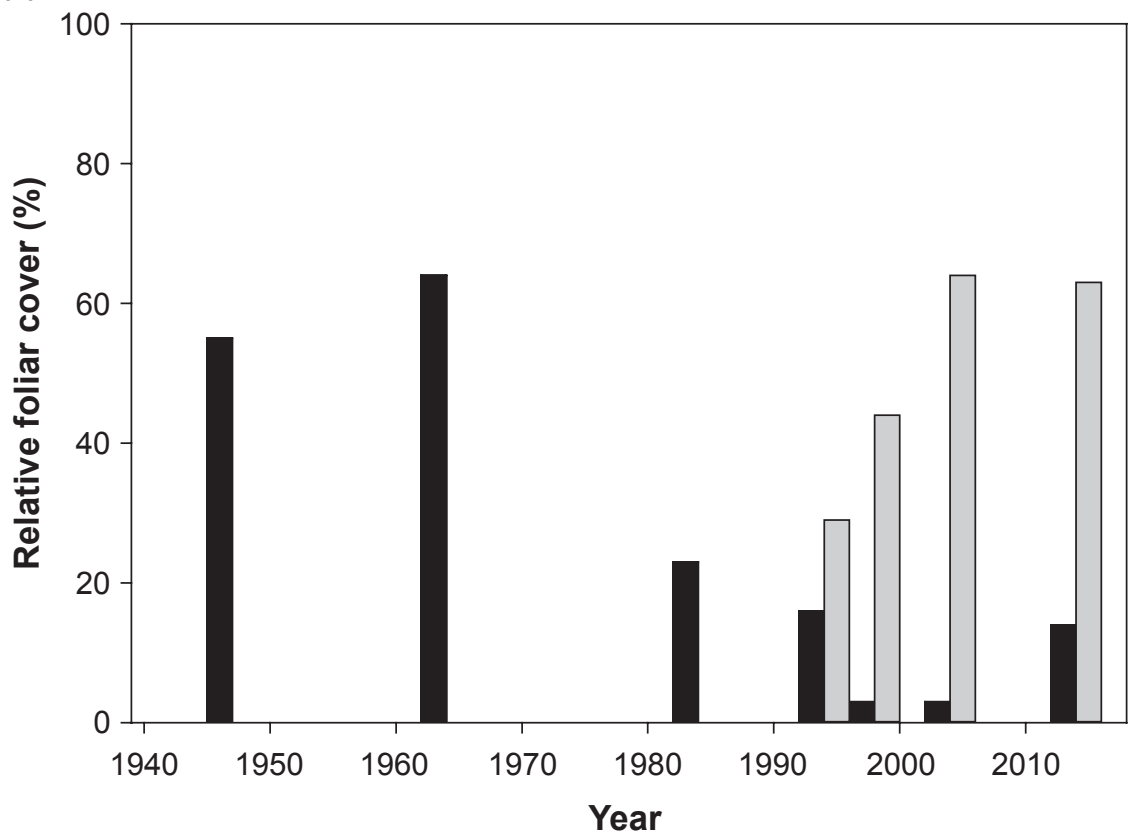

(b)

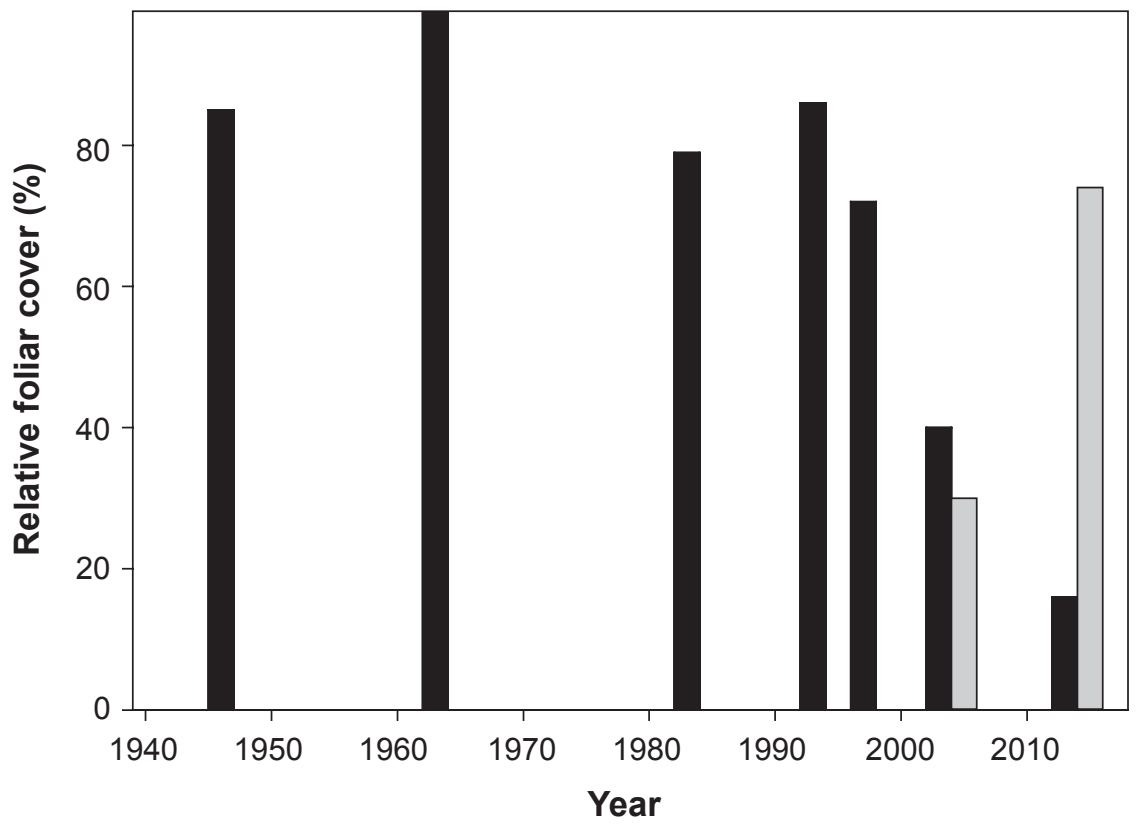

Legend

Blue grama

Kentucky bluegrass 


\section{Figure 3}

Field technician conducting research on invasive species in the long-term pastures in 2014 .

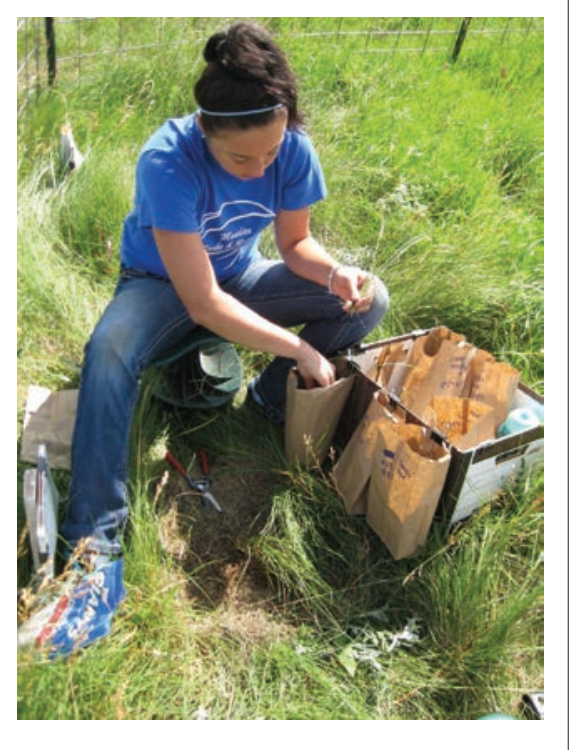

\section{SOIL CARBON SEQUESTRATION AND GREENHOUSE GAS EMISSIONS}

In response to concerns about global climate change and atmospheric carbon dioxide $\left(\mathrm{CO}_{2}\right)$ concentrations, the 1990s saw new research on $\mathrm{CO}_{2}$ exchange dynamics and the capacity for soil C storage on native grasslands. Precision measurements in several years on the longterm pastures demonstrated that northern mixed-grass prairie was a small sink for C, but that dormant-season $\mathrm{CO}_{2}$ fluxes controlled whether the grassland would be a sink or source for C (Frank 2004). The $\mathrm{CO}_{2}$ flux studies were originally part of a rangeland $\mathrm{CO}_{2}$ flux network and were later incorporated into the Greenhouse Gas Reduction through Agricultural Carbon Enhancement network (GRACEnet, http://www.ars.usda.gov/research/gracenet), both led by the USDA Agricultural Research Service (ARS). In follow-up research, scientists at the NGPRL determined that net global warming potential was negative for prairie pastures, implying net removal of greenhouse gases from the atmosphere (Liebig et al. 2010). Lower stocking rates were more effective at achieving net reductions in greenhouse gas emissions, but at a cost of sacrificing cattle production (table 1). Collectively, longterm soil $\mathrm{C}$ and greenhouse gas research

\section{Table 1}

Net global warming potential of long-term grazing on native rangelands at Mandan, North Dakota, expressed as $\mathrm{CO}_{2}$-equivalents $\left(\mathrm{CO}_{2 \mathrm{e}}\right)$.

\begin{tabular}{llcc}
\hline Variable & Light stocking & Heavy stocking & Change \\
\hline Global warming potential $\left(\mathrm{kg} \mathrm{CO}_{2 \mathrm{e}} \mathrm{ha}^{-1} \mathrm{y}^{-1}\right)$ & $-783 \dagger$ & -618 & 165 \\
Gain ha & \\
Greenhouse gas intensity $\left(\mathrm{kg} \mathrm{CO}_{2 \mathrm{e}} \mathrm{kg}^{-1}\right.$ gain $)$ & -145 & 28 & -22 \\
\hline †Negative values imply net $\mathrm{CO}_{2}$ uptake from the atmosphere (adapted from Liebig et al. [2010]).
\end{tabular}

on the historical pastures underscored the value of grazed, mixed-grass prairie as a viable agroecosystem for mitigating climate change. Continuing research focuses on larger efforts to scale up site measurements to the regional scale via remote sensing and vegetation indices.

\section{NETWORKING FOR NEW OPPORTUNITIES IN THE FUTURE}

Many of the earth's processes and systems have been altered (sometimes dramatically) by humans (Crutzen 2002). Science agencies such as the USDA ARS and the National Science Foundation (NSF) recognize the need for new long-term research to learn how to cope with and adapt to profound changes such as population increases, land use change, and greenhouse gas emissions. These agencies have formed two national networks to conduct longterm agricultural and ecological research, the USDA Long-Term Agroecosystem Research network (LTAR, http://www. ars.usda.gov/ltar) and the NSF-funded National Ecological Observatory Network (NEON). The long-term pastures at the NGPRL contribute to both networks and will continue to serve as a unique longterm research site for the future.

Long-Term Agroecosystem Research Network. The USDA LTAR network is composed of 18 research sites across the United States (Walbridge and Shafer 2011) and is focused on conducting longterm, transdisciplinary science supporting the sustainable intensification of agricultural systems. This national network will develop an understanding of how to sustain or enhance agricultural production at the watershed/landscape scale to meet increasing demands for agricultural goods and services against a background of climate change. The long-term prairie pastures at the NGPRL will be incorporated into a new 30-year, multilocation common experiment as part of the network. The approach at the NGPRL will be to evaluate selected ecosystem services and metrics in a typical extensive livestock grazing system (the long-term pastures) and a typical dryland cropping system compared with a dynamic integrated cropping system. The site will be instrumented to measure productivity, C fluxes, water balance, erosion, and biodiversity, among several other biophysical variables. The livestock, soils, and vegetation data archive will also contribute to cross-location retrospective analyses.

National Ecological Observatory Network. The NGPRL was chosen to be one of the original NEON sites. The NEON network supports continentalscale ecological research within specific domains in the United States (Lowman et al. 2009). The NGPRL was chosen to represent the agricultural domain on the northern plains. As part of the network, an instrumentation tower and array have been constructed in one of the long-term prairie pastures, and the site is expected to be fully instrumented and operational in 2017. Several ecosystem attributes will be measured including $\mathrm{C}$ exchange, soil moisture, soil gas exchange, species diversity, phenology, along with other biophysical characteristics. These data, along with similar data from several other ecological domains across North America (including NEON sites at the USDA ARS Jornada Experimental Range in Las Cruces, New Mexico, and the USDA ARS Central Plains Experimental Range in Nunn, Colorado), will be publicly available.

\section{SUMMARY}

A century ago, Johnson Thatcher Sarvis and scientists at Mandan set out to determine the area needed to sustainably support a steer during the grazing sea- 
son. In addition to answering the original question, scientists gathered some of the first data on grazing resilience of native grasses, determined the critical role of soil moisture in maintaining rangeland productivity on the semiarid northern plains, and generated applied ecological insights on the persistence and resilience of native prairie during the worst drought of the last millennium. Because of the foresight of Sarvis and others, this long-term study continues to serve as a unique and valuable resource. Important long-term ecological and resource management questions, such as vegetation, soil, and cattle weight gain changes with respect to weather, management, etc., simply cannot be answered with short-term data. Leveraging existing long-term data with formation of the LTAR network and NEON can allow us to peer into the future of the northern Great Plains. The question in the twentyfirst century is a similar one: how do we sustainably intensify agroecosystems in an era of climatic and social changes? Our challenge is to exhibit the same foresight and develop research that is still relevant in 100 years.

\section{ACKNOWLEDGEMENTS}

Johnson Thatcher Sarvis established the experiment in 1915 and managed it until 1940. The experiment was continued by George Rogler from 1940 to 1952, Russell Lorenz and George Rogler from 1953 to 1973 , Russell Lorenz from 1974 to 1979 , Lenat Hofmann from 1980 to 1992, and Jim Karn from 1993 to 2002. Numerous technicians and part-time students were also involved in the day-to-day management and conduct of the experiment. We would like to recognize these scientists and support staff for their extraordinary foresight and determination in skillfully managing and continuing this experiment into the twenty-first century. Thanks also to Holly Johnson at the Northern Great Plains Research Laboratory for organizing, cataloging, and annotating the publications from the long-term experiment. A complete list (and electronic copies) of scientific publications generated from this experiment is available at http://www.ars.usda.gov/Research/docs. $h t m$ ? docid $=25311$. The USDA is an equal opportunity provider and employer.

\section{REFERENCES}

Crutzen, P. 2002. Geology of mankind. Nature 415(3 January, 2002):23.
Frank,A.B. 2004. Six years of $\mathrm{CO}_{2}$ flux measurements for a moderately grazed mixed-grass prairie. Environmental Management 33(1):S426-S431.

Frank,A.B., D.L.Tanaka, L. Hofmann, and R.F. Follett. 1995. Soil carbon and nitrogen of Northern Great Plains grasslands as influenced by longterm grazing. Journal of Range Management 48(5):470-474.

Liebig, M.A., J.R. Gross, S.L. Kronberg, R.L. Phillips, and J.D. Hanson. 2010. Grazing management contributions to net global warming potential: A long-term evaluation in the northern Great Plains. Journal of Environmental Quality 39(3):799-809.

Lowman, M., C. D’Avanzo, and C. Brewer. 2009. A national ecological network for research and education. Science 323(27 February, 2009):1172-1173.

Reeves, J.L., J.D. Derner, M.A. Sanderson, J.R. Hendrickson, S.L. Kronberg, M.K. Petersen, and L.T.Vermeire. 2014. Seasonal weather influences on yearling beef steer production on C3-dominated Northern Great Plains rangeland. Agricultural Ecosystems and Environment 183(2014):110-117.

Reeves, J.L., J.D. Derner, M.A. Sanderson, J.R. Hendrickson, S.L. Kronberg, L.T. Vermeire, M.K. Petersen, and J.G. Irisarri. 2015. Seasonal weather-related decision making for cattle production in the Northern Great Plains. Rangelands 37(5):119-124.

Rogler, G.A., and H.J. Haas. 1947. Range production as related to soil moisture and precipitation on the northern Great Plains. Journal of the American Society of Agronomy 39(5):378-389.

Sanderson, M.A., M.A. Liebig, J.R. Hendrickson, S.L. Kronberg, D. Toledo, J.D. Derner, and J.L. Reeves. 2015. Long-term agroecosystem research on northern Great Plains prairie. Canadian Journal of Plant Science 95(6):1101-1116.

Sarvis, J.T. 1920. Composition and density of the native vegetation in the vicinity of the Northern Great Plains Field Station. Journal of Agricultural Research 19(2):63-72.

Sarvis, J.T. 1941. Grazing investigations on the northern Great Plains. North Dakota Agricultural College Bulletin 308. Fargo, ND: North Dakota Agricultural College.

Toledo, D.T., M.A. Sanderson, K.E. Spaeth, J.R. Hendrickson, and J.L. Printz. 2014. Extent of Kentucky bluegrass and its effect on native plant species diversity and ecosystem services in the Northern Great Plains of the USA. Invasive Plant Science and Management 7(4):543-552.
Walbridge, M.R., and S.R. Shafer. 2011. A longterm agro-ecosystem research network. In Observing, studying, and managing for change-Proceedings of the Fourth Interagency Conference on Research in the Watersheds, eds. C.N. Medley, G. Patterson, and M.J. Parker, M.J. US Geological Survey Scientific Investigations Report 2011-5169. 